\title{
IMPROVING STUDENTS' PHYSICS LEARNING OUTCOMES THROUGH IMPLEMENTATION OF PEER TEACHING METHOD
}

\author{
Yeni Nuriyani $^{1 *}$, Widodo Winarso ${ }^{2}$ \\ ${ }^{1}$ SMA Negeri 4 Cirebon, Jawa Barat, Indonesia \\ ${ }^{2}$ Mathematics Education Department, Institut Agama Islam Negeri Syekh Nurjati Cirebon, \\ Jawa Barat, Indonesia \\ "Email: yeninuriyani70@gmail.com
}

\author{
Website: http://jurnal.uin-antasari.ac.id/index.php/itijk \\ Received: 10 December 2020; Accepted: 2 June 2021; Published: 24 June 2021
}

\begin{abstract}
Classroom action research using peer teaching methods to improve learning outcomes in physics subject circular motion. This study's subjects were students of class X MIPA 3 SMA Negeri 4 Cirebon Cirebon City, West Java Province, totaling 32 students. The data collection technique is done by test and observation. The research process was carried out in two cycles, each cycle consisting of four stages, namely: (1) action planning, (2) action implementation, (3) observation and interpretation, and (4) analysis and reflection. Based on the research that has been done, it can be concluded that there is an increase in learning outcomes in physics subject of student circular motion through the use of the Peer Teaching method. Pre-cycle data with a class average of 60.94 with a percentage of $28.13 \%$ complete learning or 9 students out of 32 students. The first cycle increased to $72.19 \%$ or 17 students completed with an average student grade of $53.13 \%$, but this score had not yet reached the KKM that had been agreed upon. The second cycle increased to $81.25 \%$, or 26 students completed with an average student score of 84.84. Thus, the peer teaching method's application can improve learning outcomes in the Physics subject of circular motion so that it is feasible to be applied in SMA Negeri 4 Cirebon
\end{abstract}

Key Words: learning methods; peer teaching; learning outcomes; physics

\section{INTRODUCTION}

Learning is closely related to learning outcomes. Learning is a process of constructing active student behavior towards change that is deliberately created to gain knowledge and understanding of the material whose results are manifested in student learning outcomes (Gasong, 2018). Meanwhile, students' learning outcomes are abilities after receiving their learning experiences (Winarso, 2018).

Learning outcomes play an important role in the learning process. The process of assessing learning outcomes can provide information to teachers about student progress in achieving their learning goals through learning activities (Astra, Wahyuni \& Nasbey, 2015). Furthermore, from this information, the teacher can arrange and foster further student activities, both for the whole class and individually (Kurniawan, Perdana, \& Kurniasari, 2018).

One of the problems faced by the world of education today is physics's low value (Hastuti, Sahidu, \& Gunawan, 2017). This can be seen from the decline in school exam scores. Students are considered difficult physics subjects, both in terms of the formulation and discussion of questions that are too complicated (Putra, \& Wiza, 2019). To overcome this problem, the teacher should choose strategies and effective learning methods to increase better learning outcomes (Gunawan, Ulfatin, Sultoni, Sunandar, Kusumaningrum \& Triwiyanto, 2017).

Several problems occur in this class, including students' insufficient and uneven understanding. Some students quickly understand the teacher's explanation, and some students are slow to accept the 
teacher's explanation. Lack of student participation in classroom learning shows that students rarely ask the teacher if the student is not clear about the material and the lack of students who want to express their opinion in class except for certain students. Many students feel bored with learning Physics, the subject of circular motion, so that during learning, students usually don't pay attention, many daydreams, or do other activities outside of learning.

The results of preliminary studies namely, The feeling of boredom from students can be caused by the teacher's learning methods that do not vary, namely lectures, questions and answers, and assignments only. From the results of interviews with students, most students had less positive perceptions of the teacher. The teacher's explanation was too fast. The teacher only paid attention to students who wanted to listen to the lesson. Also, students also feel afraid and tense in learning, so that this condition creates a distance between teachers and students.

\section{Table 1}

\begin{tabular}{lll}
\multicolumn{3}{l}{ Data on Learning Outcomes in Pre Cycle } \\
\hline \multirow{2}{*}{ Criteria } & $\begin{array}{l}\text { Number of } \\
\text { Students }\end{array}$ & Percentage \\
\hline$<75$ & 23 & $71,87 \%$ \\
$\geq 75$ & 9 & $28,13 \%$ \\
\hline
\end{tabular}

The pre-cycle data was conducted by researchers in class X MIPA 3 SMA Negeri 4 Cirebon; the pre-cycle average score was 60.94. This figure does not meet the KKM value (Minimum Completeness Criteria) in physics in the subject of circular motion, namely $\geq 75$. students who scored $\geq 75$ were $28.13 \%$ of the total, and the remaining $71.87 \%$ were still below the minimum completeness standard.

Considering the problems that occur especially in class X MIPA 3 SMA Negeri 4 Cirebon, it is necessary to look for an effective physics learning method. It can increase students' understanding of circular motion itself and increase student participation so that student learning outcomes increase. The use of appropriate methods in the teaching and learning process can generate desire and interest in learning, generate motivation and stimulation of learning activities, and positively impact students (Ulstad, Halvari, Sorebo, \& Deci, 2016).

There are three patterns in group learning. The first pattern is peer-to-peer teachings, where a student with a good understanding of the concept teaches a friend who doesn't understand when they work together. The second pattern is the cooperative pattern, grouping students heterogeneously with the member pattern consisting of a student with a high understanding, a student with moderate understanding, and two students with average understanding. The third pattern is the collaboration of students with the same ability to work together (Damon \& Phelps, 1989; Romano \& Brna, 2001; Ladyshewsky, 2006).

There is no visible positive impact of applied group learning caused by random group determination in ordinary group learning activities. Only based on closest friends or familiar friends, not using a specific grouping pattern. One important aspect that supports group learning success is determining the group's composition, namely how students are grouped. Group learning that can improve learning outcomes applies certain patterns in its formation to create specific interaction patterns among group members (Gillies, 2016).

Implementing the collaborative learning method combined with the peer teaching method is one of the efforts teachers can make to improve, update, and help students understand physics concepts (Misnoraliawati, 2018; Nasihah, Supeno \& Lesmono, 2019). Meanwhile, through the implementation of the peer teaching method, students are expected to teach their friends the concepts of physics they get. The existence of collaborative learning theory combined with peer teaching methods based on knowledge development and social activity processes where students need to practice it. Students are not passive 
audiences and listeners, but students must be involved in the learning process to be better absorbed.

According to Rubin \& Hebert (1998), the peer teaching method is a learning method for students to teach other students. Students are not used as learning objects but become learning subjects. Namely, students are invited to become teachings or learning resources and a place to ask questions for their friends. Peer teachings are a learning pattern by giving assignments to a group of students who have completed the lesson material to assist students who have difficulty understanding the learning material they are learning (Zulfira, 2017). Peer learning assistance can remove awkwardness. The teacher's learning model is assumed to get different perceptions from students (Effendi, 2015).

In this way, students who become teachings can repeat and explain the material again to understand better. In this case, the role of the teacher changes. The teacher does not act as a conveyor of information but acts as director and facilitator of learning, director, and provider of facilities for the learning process. Another function is peer teachings; less active students become active because they are no longer ashamed to ask questions and express opinions freely. So, the teaching system with peer teachings will help students who are less able or less fast to accept lessons from their teachers. Peer teaching activities for students are rich in experiences that are the needs of the students themselves. Both teachings and those who are told will benefit; the instructions will gain experience, while those who are told will be more creative in receiving lessons. Thus, it can create a pleasant learning atmosphere so that students can optimize their potential, and the learning outcomes of learning Physics on the subject of student circular motion will increase.

\section{RESEARCH METHOD}

\section{Research design}

This research is a type of Classroom action research. Classroom action research is observation in the form of action on a learning activity that is deliberately raised and occurs in the classroom simultaneously (Mettetal, 2002). Classroom action research is a systematic study of efforts to improve educational practice implementation by classroom teachers by taking actions in learning (Mettetal, 2002; Khasinah, 2013). This study, using the theory of a model adopted by Kemmis and Mc Tagart (Arikunto, 2010). The Kemmis and Mc Tagart models can be seen in Figure 1 .

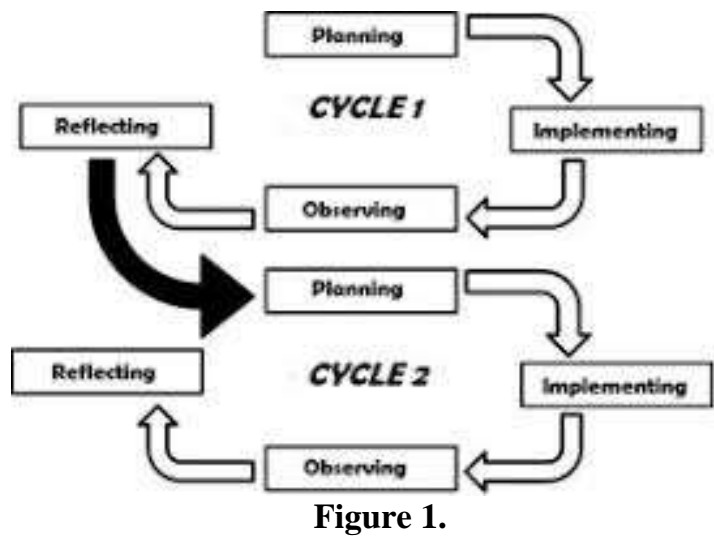

Cycle of class action research Model Kemmis and Mc Tagart (Arikunto, 2010)

\section{Research Objects and Subjects}

This classroom action research was carried out at SMA Negeri 4 Cirebon, located at Jalan Perjuangan No.1 Cirebon City, West Java Province, which was carried out in semester 1 of the 2018/2019 academic year. The research subjects were students of class X MIPA 3 SMA Negeri 4 Cirebon, with the first reason being the lack of learning outcomes in physics subject of circular motion in class X MIPA 3 SMA Negeri 4 Cirebon, with the consideration that similar research had never been used, so that it avoided the possibility of re-research. On the same subject, time, and object. The objects in this classroom action research (CAR) are the various activities that occur in the classroom during the learning process, which consists of:

1. Selection of learning methods.

2. Implementation of the chosen learning method, namely the Peer Teaching learning method. 
3. The learning atmosphere during the teaching and learning process.

4. Student participation in the learning process.

5. The results of the learning process.

\section{Data analysis technique}

The data analysis technique used is the descriptive data analysis technique. The analysis technique is used to describe the data obtained (Boudah, 2019). The function of data analysis techniques is used to get an overview of learning outcomes. The success indicator is a criterion used to see the level of success of Classroom Action Research (CAR) activities in improving the classroom's teaching and learning process. In this study, researchers target success from learning outcomes, namely KKM $\geq 75$ with an average grade completeness $\geq$ of $75 \%$. Based on the indicators of the success of learning outcomes for the initial state, the students' scores were obtained from observing the initial conditions. In contrast, the first cycle and the second cycle were obtained from researchers' results in class.

\section{RESULT AND DISCUSSION}

The peer teaching-learning method is learning that is carried out by dividing the class into small groups, and the learning resource is the teacher and peers who are clever and fast in mastering certain materials. In this learning, students who become teachings should have higher abilities than other friends so that when students provide guidance, students can already master the material presented (Qudsi, 2014).

However, to support the success of the peer teaching model, the implementation of peer teaching-learning must pay attention to things including: (1) starting with clear objectives; (2) explain the purposes of peer teaching to all students; (3) prepare adequate learning materials and resources; (4) avoid repetition that the teacher has done; (5) focuses on thinking skills; (6) provide a brief exercise on what teaching does; and (7) observing the teaching-learning process (Irmawati \& Ashar, 2016).

The steps for implementing the method of peer teaching in physics learning are as follows.

The first stage of learning is oriented towards problems that students must solve. At this stage, students are first divided into groups and given problems. Peer tutors play a role in motivating their friends to argue about existing problems, providing stimulus so that their friends have an opinion and can relate problems to everyday life.

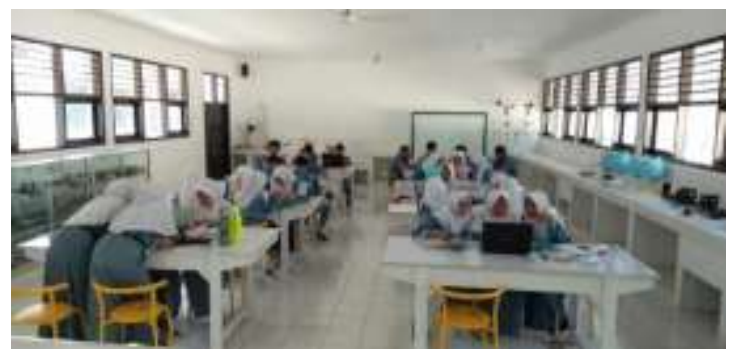

Figure 2.

Study Groups and Problem-Solving

The second stage of learning is organizing the problem. At this stage, the tutor helps his friends to write hypotheses about the problems given. The tutor can only assist in formulating hypotheses on the problem without correcting his peers' right or wrong opinions.

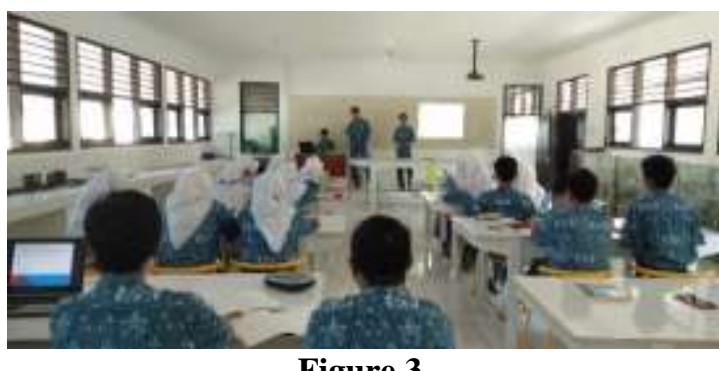

Figure 3.

Learning Activities - Organizing Problem and Hypothesis

The third stage of learning is guiding individual and group investigations. At this stage, the tutor helps his friends collect data and information to prove the correctness of the hypotheses that have been made. Tutors help students who feel confused and guide data and information collection activities. Students carry out activities according to the 
tutor's direction and ask questions they did not understand during the learning process. At this stage, it is known whether the proposed hypothesis is appropriate or not with the data obtained. Students also analyze why these things can happen.

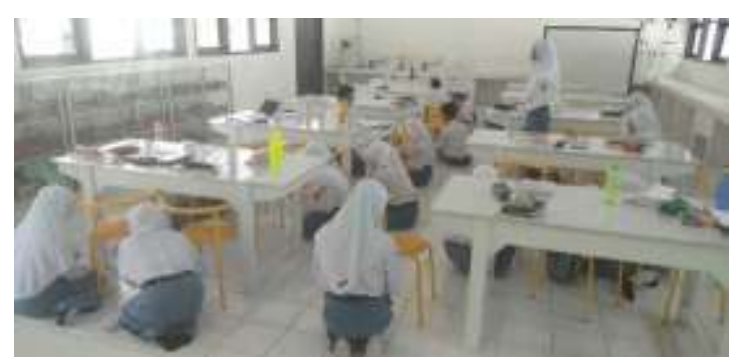

Figure 4.

Learning Activities - Collecting Data and Proving a Hypothesis

The fourth stage of learning is developing and presenting the work. At this stage, the tutor plays a role in assisting students in presenting the data obtained, shown in several representations. Also, each group came to the front of the class to present the data results and the discussions carried out with the group.

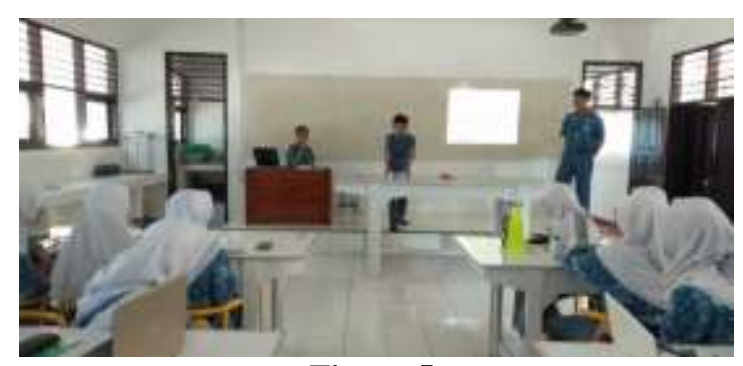

Figure 5.

Learning Activities - Present The Data Results and The Discussions

The fifth stage of learning is to evaluate. At this stage, the teacher helps students reflect on the problems that have been studied. The teacher straightens things related to the problems that have been given.

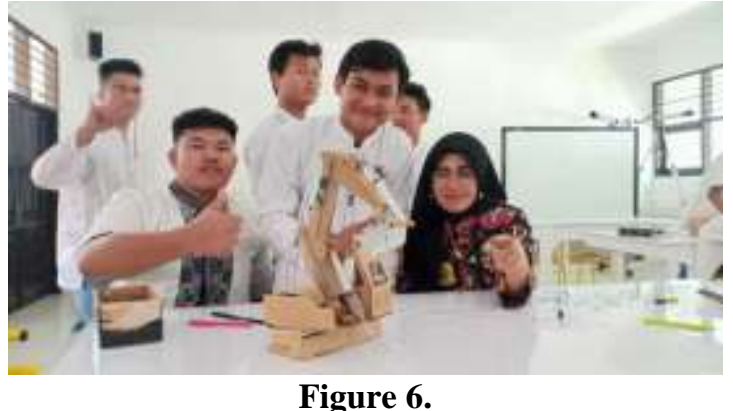

Learning Activities - The Teacher Helps Students Reflect on The Problems

The research process was carried out in two cycles, each of which consisted of 4 stages, namely: (1) action planning, (2) action implementation, (3) observation and interpretation, and (4) action analysis and reflection. The data on student physics learning outcomes at SMA Negeri 4 Cirebon based on the stages of Pre Cycle, Cycle I, and Cycle II are presented in Figure 7 below.

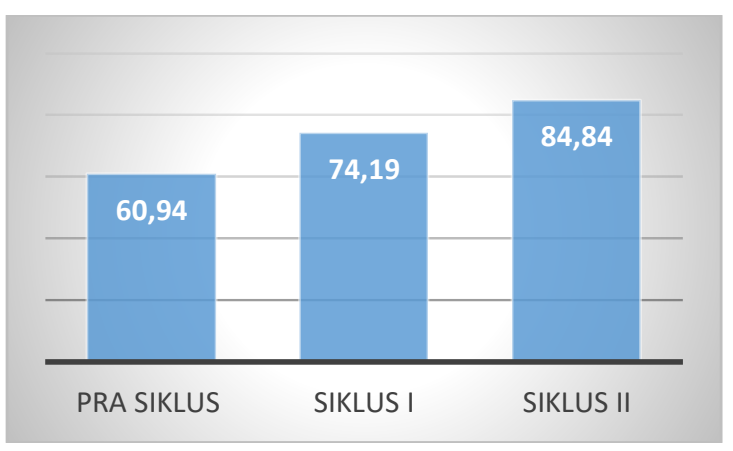

Figure 7.

Average Physics Learning Outcomes

Based on Figure 7, it is found that the average physics learning outcomes of students at SMA Negeri 4 Cirebon have increased. In the pre-cycle, the average physics learning outcome was 60.94. While in Cycle I, it was 74.19, and in Cycle II, it was 84.84. This condition means that the peer teaching method's application can improve student learning outcomes at SMA Negeri 4 Cirebon. There is an increase in improving the learning process in applying peer teaching methods to student physics learning outcomes. This is in line with the statement that group learning by following a pattern can positively impact group learning. It appears in selecting peer teaching group learning patterns, which have proven 
effective in improving student physics learning outcomes (Kusumah \& Septian, 2018; Misnoraliawati, 2018). As for more details, the results and discussion of research in each area are as follows.

\section{Learning Outcomes Data Cycle I}

\section{a) Analysis}

From the results of the data obtained by the initial observer, the teaching and learning process that has been carried out is analyzed: the learning process is not smooth and fun so that because students are less enthusiastic in receiving lessons, and the teacher does not use varied approaches, strategies and learning methods.

b) Synthetic

In this cycle, the learning process that has been carried out, starting from planning to the end of the activity, has not improved students' understanding in accordance with what is expected by the teacher. This is because there are still weaknesses that are found so that it is still an obstacle in achieving an increase in student understanding so that learning is needed in the next second cycle.

c) Evaluation

Based on the data results, the learning process in cycle I show that the learning process of growth material in plants shows that student achievement is classically still below the standard, namely from 32 students. The average class score is 72.19. The percentage of completeness learn $53.13 \%$ or 17 students complete out of 32 students, this score is still far from the minimum overall minimum completeness and a minimum level of KKM. Hence, it is necessary to do the second cycle again.

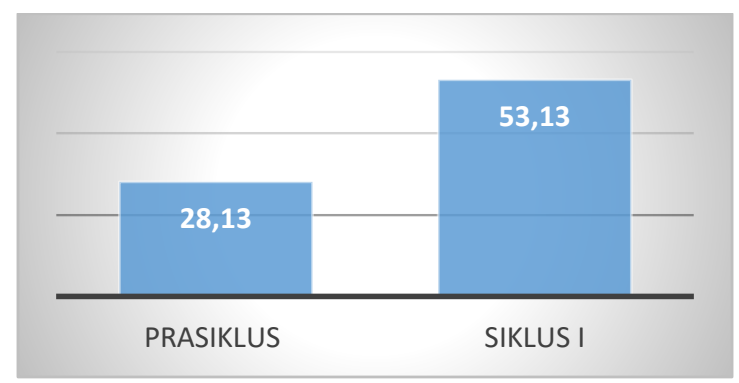

Figure 8.

\section{Percentage of KKM Achievement in Pre cycle and Cycle I}

Based on Figure 8, it is found that students' physics learning outcomes tend to be low, marked by the number of students who have not reached the minimum completeness criteria (KKM), where the KKM in physics subjects at SMA Negeri 4 Cirebon is in the pre-cycle of $28.13 \%$. At the same time, in Cycle one, it is as big as $53.13 \%$, so that the improvement of learning in the application of the peer teaching method was continued in cycle II.

\section{Data on Learning Outcomes in Cycle II}

The results of the observation of the learning process in cycle II show the following:

1. Students begin to be more active in group learning activities because they have provided a lot of additional guidance and enrichment or explanation.

2. Students can more quickly apply Preparation, Implementation, and Results in Physics learning activities, the subject of circular motion. The teacher has tried to apply Critical Thinking to Improve Student Learning Outcomes in Class X MIPA 3 SMA Negeri 4 Cirebon In physics learning, the subject of circular motion Student learning outcomes increased significantly to a grade average of 84.84 and had a completeness score of $81.25 \%$ or 26 students completed out of 32 students and had exceeded KKM $\geq 75$ and a minimum completeness score of $\geq 75 \%$. 


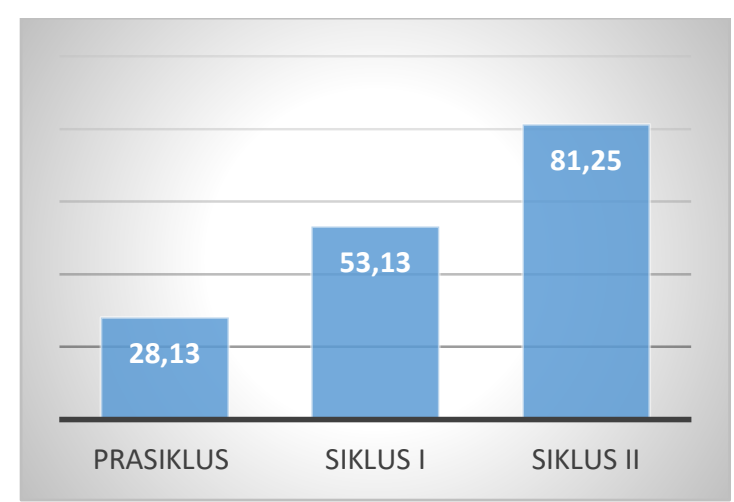

Figure 9.

Percentage of KKM Achievement

Based on observations in the second cycle stage, the reflection on students' physics learning outcomes at SMA Negeri 4 Cirebon is as follows.

\section{a) Analysis}

After the second cycle was followed, with classes carried out by the planning and learning scenarios, the learning process went well and perfectly, and the class atmosphere was conducive.

b) Synthetic

From the analysis results above, it can be concluded that the weaknesses and deficiencies in the learning process cycle have been appropriately resolved. In other words, the improvement of learning Physics subject of circular motion in Class X MIPA 3 SMA Negeri 4 Cirebon has succeeded in improving student learning outcomes.

c) Evaluation

The results of the evaluation of the process of improving learning Physics learning in the subject of circular motion in Class X MIPA 3 SMA Negeri 4 Cirebon by applying critical thinking to Improve Learning Outcomes of learning Physics subject of the circular motion of students in class X MIPA 3 SMA Negeri 4 Cirebon proves that changes in results Student learning is the class average of 60.94 with $28.13 \%$ completeness of study or 9 students complete from 32 students in pre-cycle, changing to 84.84 with $81.25 \%$ completeness learning or 26 students completing from 32 students in class $\mathrm{X}$ MIPA 3 SMA Negeri 4 Cirebon in cycle II.

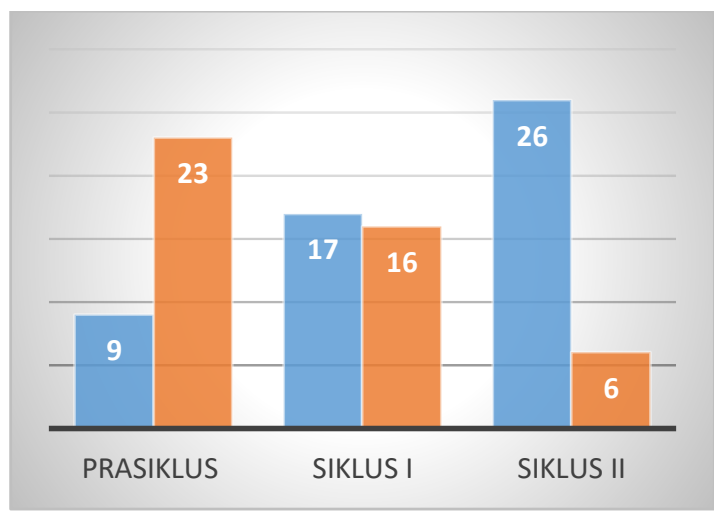

Figure 10.

Student Learning Completeness Results

Based on Figure 10, this success can be observed based on alternative solutions used to improve student learning outcomes. Some of the ways that are done include replacing students who become teachers, giving the learning more responsibility to lead and organizing the discussion, allowing each group member to ask questions, providing motivation to discuss actively. Encouraging group members not to ask questions. to the teacher during the discussion process in addition to the teaching.

Changes in teachings, motivation and longer adaptation times make students more confident in the discussion process. This can be seen in the implementation of cycle II. All students were seen to be active in group discussions. Both argue, argue, ask, or answer questions from other students. Teachings also became more confident in leading discussions and seemed to motivate their members to ask questions and complete assignments correctly. High learning outcomes are due to the confidence that students already have as teachings and as learners in carrying out activities in the group discussion process. Self-confidence is very influential in student learning achievement at school (Zenti, 2019).

\section{CONCLUSION}

Students look enthusiastic and enthusiastic in participating in learning Physics on the subject of circular motion. Student participation in learning shows an increase. Students realize that cooperation in 
groups is important to complete a task together. With collaboration in groups, they can ask the teaching things they don't understand without having to be ashamed to ask questions and express opinions. They can exchange opinions with each other, explain everything they think, and open up to their friends' thoughts. Students who actively participate in cooperative group discussions experience increased collaborative group discussions during the learning process. Students can also understand the material provided by the teacher so that the application of the peer teaching method can improve the learning outcomes of class X MIPA 3 SMA Negeri 4 Cirebon.

\section{REFERENCES}

Astra, I., Wahyuni, C., \& Nasbey, H. (2015). Improvement of Learning Process and Learning Outcomes in Physics Learning by Using Collaborative Learning Model of Group Investigation at High School (Grade $\mathrm{X}$, SMAN 14 Jakarta). Journal of Education and Practice, 6(11), 75-79. Retrieved from https://eric.ed.gov/?id=EJ1081730

Boudah, D. J. (2019). Conducting Educational Research:" Guide to Completing a Thesis, Dissertation, or Action Research Project". SAGE Publications, Incorporated. https://doi.org/10.4135/97814833491 38.n1

Damon, W., \& Phelps, E. (1989). Critical distinctions among three approaches to peer education. International journal of educational research, 13(1), 9-19. https://doi.org/10.1016/08830355(89)90013-X

Effendi, E. (2015). Hubungan persepsi siswa terhadap penerapan model pembelajaran kooperatif tipe teaching sebaya dengan prestasi belajar fisika. Jurnal Pendidikan Fisika, 3(2), 14-24.

https://doi.org/10.24127/jpf.v3i2.232
Gasong, D. (2018). Belajar dan pembelajaran. Yogyakarta: Deepublish.

Gillies, R. M. (2016). Cooperative learning: Review of research and practice. Australian journal of teacher education, 41(3), 39-54. https://doi.org/10.4135/97814462139 $\underline{71 . n 7}$

Gunawan, I., Ulfatin, N., Sultoni, S., Sunandar, A., Kusumaningrum, D. E., \& Triwiyanto, T. (2017). Pendampingan Penerapan Strategi Pembelajaran Inovatif dalam Implementasi Kurikulum 2013. Abdimas Pedagogi: Jurnal Ilmiah Pengabdian kepada Masyarakat, $\quad 1(1) . \quad 37-47$. http://dx.doi.org/10.17977/um050v1i $1 \mathrm{p} \% 25 \mathrm{p}$

Hastuti, A., Sahidu, H., \& Gunawan, G. (2017). Pengaruh Model PBL Berbantuan Media Virtual Tehadap Kemampuan Pemecahan Masalah Fisika. Jurnal Pendidikan Fisika dan Teknologi, 2(3), 129-135. https://doi.org/10.29303/jpft.v2i3.303

Irmawati, A., \& Ashar, H. (2016). Penerapan Strategi Pembelajaran Teaching Sebaya Dalam Meningkatkan Hasil Belajar Kit Eksperimen Fisika. Jurnal Pendidikan Fisika, 4(2), 67-70.

Khasinah, S. (2013). Classroom action research. PIONIR: Jurnal Pendidikan, 4(1), 101-114.

Kurniawan, D. A., Perdana, R., \& Kurniasari, D. (2018). Identification of student attitudes toward physics learning at Batanghari District high school. The Educational Review, USA, 2(9), 475-484. https://doi.org/10.26855/er.2018.09.0 $\underline{03}$

Kusumah, M. I., \& Septian, D. (2018). Pengaruh Metode Pembelajaran Teaching Sebaya (Peer Teaching) Terhadap Hasil Belajar Siswa Pada Mata Pelajaran Fisika Pokok Bahasan Vektor Kelas X MIPA MAN 1 Cirebon. Jurnal Pendidikan Fisika 
dan Sains (JPFS), 1(1), 33-39. Retrieved from http://journal.unucirebon.ac.id/index. php/jpfs/article/view/62

Ladyshewsky, R. K. (2006). Peer coaching: A constructivist methodology for enhancing critical thinking in postgraduate business education. Higher Education Research \& Development, 25(1), 6784.

https://doi.org/10.1080/13600800500 453196

Mettetal, G. (2002). Improving teaching through classroom action research. Essays on teaching excellence: Toward the best in the Academy, 14(7), 1-4.

Mettetal, G. (2002). The What, Why and How of Classroom Action Research. Journal of the Scholarship of Teaching and Learning, 2(1), 6-13. https://doi.org/10.4135/97814522206 $\underline{97}$

Misnoraliawati, M. (2018). Efektifitas Penggunaan Metode Teaching Sebaya Terhadap Hasil Belajar Fisika Siswa Kelas Xi IPA II MAN I Palembang. Jurnal Inovasi dan Pembelajaran Fisika, 5(1), 31-42. https://doi.org/10.36706/jipf.v5i1.575 $\underline{0}$

Nasihah, E. D., Supeno, S., \& Lesmono, A. D. (2019). Model Problem Based Learning (PBL) Disertai Teaching Sebaya Untuk Meningkatkan Keterampilan Berpikir Kritis Siswa SMA. FKIP e-Proceeding, 3(2), 178 183.

https://doi.org/10.24127/jpf.v8i1.1899

Putra, D. S., \& Wiza, O. H. (2019). Analisis Sikap Siswa Terhadap Mata Pelajaran Fisika di SMA Ferdy Ferry Putra Kota Jambi. UPEJ Unnes Physics Education Journal, 8(3), 299-311. https://doi.org/10.15294/upej.v8i3.35 $\underline{631}$

Qudsi, F. T. (2014). Pembelajaran teaching sebaya materi besaran dan satuan fisika. Jurnal Pendidikan Tindakan
Kelas, 4(1).1-10.Retrieved from http://i-

rpp.com/index.php/dinamika/article/v iew/84

Romano, D. M., \& Brna, P. (2001). Presence and reflection in training: Support for learning to improve quality decisionmaking skills under time limitations. CyberPsychology \& Behavior, 4(2), 265-277. https://doi.org/10.1089/10949310130 0117947

Rubin, L., \& Hebert, C. (1998). Model for active learning: Collaborative peer teaching. College Teaching, 46(1), 2630.

https://doi.org/10.1080/87567559809 596229

Stigmar, M. (2016). Peer-to-peer teaching in higher education: A critical literature review. Mentoring \& Teachinging: partnership in learning, 24(2), 124136.

https://doi.org/10.1080/13611267.201 6.1178963

Suharsimi, A. (2010). Prosedur penelitian: suatu pendekatan praktik (edisi revisi). Jakarta: Rineka Cipta

Ulstad, S. O., Halvari, H., Sørebø, Ø., \& Deci, E. L. (2016). Motivation, learning strategies, and performance in physical education at secondary school. Advances in Physical Education, 6(1), 27-41. https://doi.org/10.4236/ape.2016.6100 $\underline{4}$

Winarso, W. (2018). Authentic assessment for academic performance: study on the attitudes, skills, and knowledge of grade 8 mathematics students. Malikussaleh Journal of Mathematics Learning (MJML), 1(1), 1-8.

https://doi.org/10.29103/miml.v1i1.57 $\underline{9}$

Zenti, E. (2019). Peningkatan Aktivitas Belajar Peserta Didik melalui Model Pembelajaran Kooperatif dengan Metode Teaching Sebaya. Jurnal Kinerja Kependidikan (JKK), 1(1), 1- 
17.

https://doi.org/10.29210/12017297

Zulfira, T. (2017). Pengaruh Metode

Pembelajaran Collaborative Learning

Dipadu Dengan Metode Teaching

Sebaya Terhadap Hasil Belajar Fisika

Siswa. Jurnal Ilmiah Mahasiswa

Pendidikan Fisika, 2(1), 175-179.

Retrieved

from

http://www.jim.unsyiah.ac.id/pendidi

kan-fisika/article/view/2229 